\title{
Vitamin D Low-Levels and Silent Myocardial Ischemia in Type 2 Diabetes: Clinical Correlations and Prognostic Significance
}

Rosario Rossi ( $\sim$ rosario.rossi@unimore.it )

University of Modena and Reggio Emilia https://orcid.org/0000-0001-9065-1808

Marisa Talarico

University of Modena and Reggio Emilia https://orcid.org/0000-0003-2523-7963

Cristina Rolando

Universita degli Studi di Modena e Reggio Emilia

Roberto Minici

University of Magna Graecia: Universita degli Studi Magna Graecia di Catanzaro

Giuseppe Boriani

Universita degli Studi di Modena e Reggio Emilia

Research

Keywords: Type 2 diabetes, serum Vitamin D, silent myocardial ischemia, diabetes complication.

Posted Date: November 18th, 2020

DOl: https://doi.org/10.21203/rs.3.rs-107272/v1

License: (9) This work is licensed under a Creative Commons Attribution 4.0 International License. Read Full License 


\section{Abstract}

BACKGROUND: Vitamin D deficiency has a pathogenetic and prognostic role in coronary artery disease. Moreover, Vitamin D has a key role in pain modulation and transmission. Diabetic patients have a high risk of silent myocardial ischemia (SMI), due to diabetic neuropathy. We aimed to evaluate the correlation between SMI and Vitamin D serum levels in a population of type 2 diabetic patients and to assess whether SMI patients had a worse survival than their symptomatic counterpart.

METHODS: In this retrospective, cross-sectional, observational study, we enrolled 253 patients admitted in Policlinico of Modena Hospital and compared them with 50 healthy volunteers. We divided the 253 patients into three sub-groups: symptomatic MI group (125, 32.4\%); SMI (78, 25.7\%), and no-MI one (50, $41.9 \%)$. The entire population had a 25-hydroxyvitamin D (25(OH)D) measurement.

RESULTS: 25(OH)D levels (nmol/l) were lower in SMI group (34.9 \pm 5.8$)$ respect to symptomatic MI (49.6 $\pm 6.1 ; \mathrm{p}=0.01)$; no $\mathrm{Ml}(53.1 \pm 6.2 ; \mathrm{p}=0.001)$ and control group $(62.1 \pm 6.7 ; \mathrm{p}=0.0001) .25(\mathrm{OH}) \mathrm{D}$ level was the only independent variable able to influence the development of SMI in diabetic patients, with an inverted odd-ratio of $1.11(p=0.01)$. Symptomatic Ml group had better survival than SMI one (6-year survival rate: 83 vs. $69 \% ; p=0.01$ )

CONCLUSIONS: Type 2 diabetic with SMI had a higher mortality risk and showed lower 25(OH)D levels than the symptomatic group. This suggests the crucial vitamin D role in the pathogenesis of SMI.

\section{Background}

Vitamin D or $25(\mathrm{OH})$ D is a fat-soluble hormone obtained either by sunlight exposure (ultraviolet $\mathrm{B}, 290-$ $320 \mathrm{~nm}$ ) or through dietary source and supplements, absorbed by the intestine (1). The world is actually in a state of hypovitaminosis $D$, primarily due to less exposure to sunlight. Other factors that also influence vitamin D level are age, gender, ethnicity, skin color, season, and clothing (2). It is estimated that 1 billion people worldwide suffer from vitamin D deficiency (3): more than $40 \%$ of the USA and European and even $80 \%$ of the Italian population $(4,5)$.

Low $25(\mathrm{OH})$ D levels were associated with cardiovascular disorders, including heart failure, stroke, and especially coronary heart disease (CAD) (6-10). Besides, 25(OH)D deficiency was associated with endothelial dysfunction, subclinical atherosclerosis, significant reduction of coronary flow reserve (11, 12), and sub-epicardial ischemia in patients hospitalized for the acute coronary syndrome (13).

CAD is a leading cause of death in type 2 diabetes patients. In the diabetic population silent, myocardial ischemia (SMI) is extremely common and carries a higher risk of severe complications than symptomatic MI (14-17). SMI is the result of an 'anginal warning system' failure, resulting in a delay in anti-ischemic therapy $(17,18)$. Moreover, the pathophysiology of SMI in diabetic patients is poorly understood $(19-21)$. In line with other previous large studies that demonstrated a potential correlation between $25(\mathrm{OH}) \mathrm{D}$ 
deficiency and subclinical myocardial injury and with sensitive neuropathy (22-25), we hypothesized that vitamin D deficiency is correlated to SMI.

Among the studies reporting a strong association between low 25(OH)D levels and $\mathrm{MI}$, none differentiated between patients with silent myocardial ischemia (SMI) or symptomatic one, even if $25(\mathrm{OH}) \mathrm{D}$ may be related to one or another sub-type. There is thus a clear rationale for measuring $25(\mathrm{OH}) \mathrm{D}$ levels in carefully characterized type 2 diabetic patients with CAD and MI.

The purpose of the present study is two-fold. First, we established the importance of vitamin D levels on SMI development; and second, we compared the prognosis of diabetic patients with silent to the prognosis of diabetic patients with symptomatic MI, to assess whether SMI patients had a worse survival (as expected) than their symptomatic counterparts.

\section{Methods}

\section{Study population, setting, and data collected}

In this single-center, cross-sectional, retrospective, observational study, we enrolled from 01 January 2000 and 31 December 2013, 2407 diabetic patients with suspected CAD who underwent coronary angiography at the Catheterization Laboratory of the Policlinico di Modena Hospital. The current study protocol is in accordance with the Declaration of Helsinki and obtained the approval of the Ethics Committee of Modena University the 20/05/2020 with protocol number 0014071/20.

Patients with primary valvular, congenital, myocardial and pericardial disease, as well as patients with previous surgery or percutaneous revascularization, previous acute coronary syndromes and/or EKG pathological Q waves, were excluded. Among the eligible patients, 960 patients also had an exercise test within 6 weeks of catheterization. In this group of patients, 203 were found to have significant CAD ( $\geq$ $70 \%$ diameter stenosis in at least one of the main coronary branches; or $\geq 50 \%$ in the left main) on coronary angiography and had $\geq 0.10 \mathrm{mV}$ exercise-induced ST-segment depression at EKG. The last patients, together with a group of 50 patients with type II diabetes and no $\mathrm{Ml}$, and 50 healthy, age- and gender-related non-diabetic control subjects, constituted the total selected population. All enrolled patients had at least one $25(\mathrm{OH}) \mathrm{D}$ serum determination until 12 months before catheterization in the year of catheterization. At six and 12 months after catheterization, and then yearly, follow-up information was obtained by clinic visit, telephone interview, or a combination. Follow-up was obtained for $95 \%$ of the studied population.

\section{Assessments of vitamin D status}

Vitamin D is a steroidal substance that is mainly produced in the skin by direct exposure to sunlight. The principal forms of vitamin D are cholecalciferol (D3) and ergocalciferol (D2). The human body cannot produce $D 2$, but it may be ingested in the form of supplements. Vitamine $D$ is not biologically active as D3. It undergoes successive hydroxylations in the liver and kidney, to form the active hormone 1,25- 
dihydroxyvitamin $D$ (calcitriol). The major storage form of vitamin $D$ is $D 2$ (25-hydroxyvitamin $D$ [25(OH)D]), with plasma levels more than 1000-fold greater than the active 1,25-dihydroxyvitamin D. Hence, 25(OH)D measurement is considered to be adequate to calculate overall vitamin D status. We used a chemiluminescence immunoassay method for the quantitative determination of total serum 25(OH)D (DiaSorin, Stillwater, MN, USA). People on vitamin D oral supplementation were excluded, as were those using sunbeds.

\section{Statistical analysis}

All analyses were performed using the statistical package SPSS, version 22.0 (IBM Corp., Armonk; NY, USA). Baseline characteristics were expressed as mean \pm one standard deviation (SD) or standard error of the mean (SEM) when specified. Categorical variables were described as percentages. One-way analysis of variance (ANOVA) was used to compare the mean of baseline characteristics and post hoc analysis to make comparisons between the group means; and $\chi^{2}$ test for dichotomous variables. Analysis of covariance (ANCOVA) was performed to examine differences in mean serum vitamin $D$ levels between the study groups using age, gender, BMI, and season of vitamin D measurement as covariates. Direct logistic regression was executed, and odds ratios were calculated to assess the impact of various potentially independent factors on SMI. Survival probabilities were estimated using the Kaplan-Meier method. Breslow's formulation of the Cox proportion hazard model was used to test for a significant association between survival time and the presence of SMI. Differences were considered statistically significant when the $p$-value was $<0.05$.

\section{Results}

Table 1 summarize demographic details and study assessments performed for each group. Patients with SMI had a higher body mass index (BMI) and were older compared to patients with symptomatic MI. The SMI group demonstrated a longer duration of diabetes, but there were no significant differences in $\mathrm{HbA} 1 \mathrm{c}$ between them. After adjusting for age, gender, BMl, and season of vitamin $D$ measurement, $25(\mathrm{OH}) \mathrm{D}$ levels (nmol/I) (SE) were significantly lower in patients with SMI $(34.9 \pm 5.8)$ respect to patients with symptomatic $\mathrm{MI}(49.6 \pm 6.1 ; \mathrm{p}=0.01)$; no MI $(53.1 \pm 6.2 ; \mathrm{p}=0.001)$; and healthy volunteers $(62.1 \pm 6.7 ; \mathrm{p}=$ 0.0001). Pairwise comparisons revealed the main group significance between patients with silent respect to symptomatic MI (see Table 1). Direct logistic regression was performed to assess the impact of all potential independent variables on the presence of SMI. The full model that emerged was statistically significant $\left(\chi^{2}=27.3, p=0.001\right)$. As shown in Table 2 , vitamin $D$ was the only independent variable that made a statistically significant contribution to the model, with an inverted odd ratio of $1.11(p=0.01)$. For each unit reduction in vitamin $\mathrm{D}$, the likelihood of SMI increased by $11 \%$. 
Table 1

Demographic, clinic and catheterization characteristics of our study population.

\begin{tabular}{|c|c|c|c|c|c|}
\hline c & $\begin{array}{l}\text { Healthy } \\
\text { volunteers }\end{array}$ & $\begin{array}{l}\text { No } \\
\text { myocardial } \\
\text { ischemia }\end{array}$ & $\begin{array}{l}\text { Symptomatic } \\
\text { myocardial } \\
\text { ischemia }\end{array}$ & $\begin{array}{l}\text { Silent } \\
\text { myocardial } \\
\text { ischemia }\end{array}$ & $\begin{array}{l}\text { Post hoc p-value, } \\
\text { comparing silent and } \\
\text { symptomatic } \\
\text { ischemia }\end{array}$ \\
\hline $\mathrm{n}$ & 50 & 50 & 125 & 78 & \\
\hline \multicolumn{6}{|c|}{ Demographic and anthropometric parameters } \\
\hline Age, years & $62.0 \pm 9.0$ & $55.4 \pm 8.2$ & $61.9 \pm 9.4$ & $64.1 \pm 10.3$ & 0.03 \\
\hline Male gender, \% & $\begin{array}{l}72.0(n= \\
36)\end{array}$ & $\begin{array}{l}80.0(n= \\
40)\end{array}$ & $72.0(n=90)$ & $\begin{array}{l}71.8(n= \\
56)\end{array}$ & 0.7 \\
\hline Ethnicity & Caucasian & Caucasian & Caucasian & Caucasian & \\
\hline \multicolumn{6}{|c|}{ Coronary risk factors } \\
\hline $\mathrm{BMI}, \mathrm{kg} / \mathrm{m}^{2}$ & $26.1 \pm 4.6$ & $30.1 \pm 6.7$ & $31.1 \pm 5.5$ & $33.8 \pm 6.6$ & 0.04 \\
\hline $\begin{array}{l}\text { Diabetes } \\
\text { duration, years }\end{array}$ & & $6.5 \pm 6.0$ & $13.5 \pm 7.0$ & $15.5 \pm 9.0$ & 0.03 \\
\hline $\begin{array}{l}\mathrm{HbA} 1 \mathrm{c} \\
\mathrm{mmol} / \mathrm{mol}\end{array}$ & & $62 \pm 16$ & $62 \pm 15$ & $65 \pm 17$ & 0.2 \\
\hline $\mathrm{HbA} 1 \mathrm{c}, \%$ & & $7.9 \pm 1.9$ & $7.9 \pm 1.6$ & $8.1 \pm 1.6$ & \\
\hline $\begin{array}{l}\text { Total } \\
\text { cholesterol, } \\
\mathrm{mmol} / \mathrm{L}\end{array}$ & & $4.1 \pm 1.4$ & $4.2 \pm 1.5$ & $4.0 \pm 1.6$ & 0.6 \\
\hline MAP, mmHg & $\begin{array}{l}91.1 \pm \\
12.8\end{array}$ & $\begin{array}{l}101.5 \pm \\
11.4\end{array}$ & $100.9 \pm 11.0$ & $\begin{array}{l}102.0 \pm \\
12.7\end{array}$ & 0.1 \\
\hline $\begin{array}{l}\text { eGFR, } \\
\mathrm{ml} / \mathrm{min} / 1.73 \mathrm{~m}^{2}\end{array}$ & $90 \pm 25$ & $82 \pm 21$ & $67 \pm 23$ & $65 \pm 24$ & 0.5 \\
\hline $\begin{array}{l}\text { Urine ACR, } \\
\mathrm{mg} / \mathrm{mmol}\end{array}$ & & $0.6 \pm 0.9$ & $4.1 \pm 7.2$ & $3.3 \pm 30.1$ & 0.1 \\
\hline $\begin{array}{l}\text { 25(OH)D, } \\
\mathrm{mmol} / \mathrm{L}( \pm \text { SEM })\end{array}$ & $62.1(6.7)$ & $53.1(6.2)$ & $49.6(6.1)$ & $34.9(5.8)$ & 0.01 \\
\hline $\begin{array}{l}\text { Summer } \\
\text { determination of } \\
25(\mathrm{OH}) \mathrm{D}, \%(\mathrm{n})\end{array}$ & $\begin{array}{l}28.0(n= \\
14)\end{array}$ & $\begin{array}{l}30.0(n= \\
15)\end{array}$ & $28.8(n=36)$ & $\begin{array}{l}29.5(n= \\
23)\end{array}$ & 0.6 \\
\hline $\begin{array}{l}\text { LVEF, median } \\
\text { (iqr), \% }\end{array}$ & $\begin{array}{l}65(60- \\
70)\end{array}$ & $\begin{array}{l}60(50- \\
70)\end{array}$ & $58(50-66)$ & $\begin{array}{l}59(52- \\
66)\end{array}$ & 0.1 \\
\hline
\end{tabular}

Legend: $A C R$, albumin creatinine ratio; $B M I$, body mass index; $C A D$, coronary artery disease; $E G R F$, estimated glomerular filtration rate; $L V E F$, left ventricle ejection fraction; iqr, interquartile range; $M A P$, mean arterial blood pressure; $n$, number; 25(OH)D, 25-hydroxy-vitamin D. 


\begin{tabular}{|llllll|}
\hline c & $\begin{array}{l}\text { Healthy } \\
\text { volunteers }\end{array}$ & $\begin{array}{l}\text { No } \\
\text { myocardial } \\
\text { ischemia }\end{array}$ & $\begin{array}{l}\text { Symptomatic } \\
\text { myocardial } \\
\text { ischemia }\end{array}$ & $\begin{array}{l}\text { Silent } \\
\text { myocardial } \\
\text { ischemia }\end{array}$ & $\begin{array}{l}\text { Post hoc p-value, } \\
\text { comparing silent and } \\
\text { symptomatic } \\
\text { ischemia }\end{array}$ \\
\hline
\end{tabular}

\section{Exercise test characteristics}

\begin{tabular}{|c|c|c|c|c|}
\hline $\begin{array}{l}\text { Exercise time } \\
\text { (iqr), min }\end{array}$ & $\begin{array}{l}8.5(7.8- \\
9.2)\end{array}$ & $4.5(3.9-5.1)$ & $\begin{array}{l}4.9(3.9- \\
5.9)\end{array}$ & 0.1 \\
\hline $\begin{array}{l}\text { Exercise heart } \\
\text { rate, median } \\
\text { (iqr), bpm }\end{array}$ & $\begin{array}{l}128(112- \\
138)\end{array}$ & $\begin{array}{l}112(105- \\
119)\end{array}$ & $\begin{array}{l}118(109- \\
127)\end{array}$ & 0.3 \\
\hline $\begin{array}{l}\text { ST depression, } \\
\text { median (iqr), } \\
\text { mm }\end{array}$ & & $\begin{array}{l}0.17(0.15- \\
0.20)\end{array}$ & $\begin{array}{l}0.20 \\
(0.12- \\
0.28)\end{array}$ & 0.2 \\
\hline
\end{tabular}

\section{Catheterization characteristics}

1-vessel CAD, \%

(n)

2-vessel CAD, \%

(n)

\section{3-vessel CAD, \%}

(n)

Left main, \% (n)

$\begin{array}{lll}20.0(n=25) & \begin{array}{l}19.3(n= \\ 15)\end{array} & 0.9 \\ 29.6(n=37) & \begin{array}{l}26.9(n= \\ 21)\end{array} & 0.4 \\ 47.2(n=59) & \begin{array}{l}50.0(n= \\ 39)\end{array} & 0.5\end{array}$

$3.2(n=4)$

$3.8(n=3)$

0.8

Legend: $A C R$, albumin creatinine ratio; $B M I$, body mass index; $C A D$, coronary artery disease; $E R R F$, estimated glomerular filtration rate; $L V E F$, left ventricle ejection fraction; iqr, interquartile range; $M A P$, mean arterial blood pressure; n, number; 25(OH)D, 25-hydroxy-vitamin D.

Table 2

Logistic regression predicting likelihood of silent myocardial ischemia.

\begin{tabular}{|lllllll|}
\hline parameter & $\boldsymbol{B}$ & SE & Wald & $\mathbf{p}$ & Odds ratio & 95\% C. I. \\
\hline Age & 0.10 & 0.06 & 2.8 & 0.09 & 1.11 & $0.98-1.25$ \\
\hline Body mass index & 0.02 & 0.06 & 1.3 & 0.22 & 1.02 & $0.92-1.20$ \\
\hline Diabetes duration & 0.08 & 0.05 & 2.5 & 0.11 & 1.08 & $0.97-1.19$ \\
\hline Male gender & 0.27 & 0.40 & 0.9 & 0.8 & 1.25 & $0.51-2.87$ \\
\hline Summer determination of 25(OH)D & 0.34 & 0.20 & 1.0 & 0.6 & 1.50 & $0.74-2.12$ \\
\hline 25(OH)D & -0.06 & 0.03 & 5.9 & 0.01 & 1.11 & $1.06-1.17$ \\
\hline constant & -11.28 & 6.9 & 2.2 & 0.10 & 0.00 & \\
\hline
\end{tabular}

At the follow-up, the majority of our patients underwent coronary revascularization: $93.6 \%$ (117 of 125) of symptomatic MI patients vs $94.9 \%$ (74 of 79 ) in the SMI group ( $p=0.3$, inter-group comparison). Detailed 
therapeutic options are shown in Table 3. We observed that the two studied groups were comparable to the type of revascularization. The median follow-up time for the study population was 6 years.

Symptomatic MI patients had a better survival rather than SMI once (6-year survival rate: 83 vs. 69\%; $p=$ $0.01 ;$ Fig. 1). It can be observed that during the first years after revascularization the survival curves appear approximately coupled. The divergence of the curves occurred from the third year onwards.

Table 3

Therapeutic options chosen for the patients of our study, divided according to the presence of angina or silent myocardial ischemia.

\begin{tabular}{|c|c|c|c|}
\hline $\begin{array}{l}\text { Therapeutic options } \\
\text { * }\end{array}$ & $\begin{array}{l}\text { Patients with } \\
\text { symptomaticmyocardial ischemia (n } \\
=125 \text { ) }\end{array}$ & $\begin{array}{l}\text { Patients with silent myocardial } \\
\text { ischemia }(n=78)\end{array}$ & $\mathrm{p}^{* *}$ \\
\hline $\begin{array}{l}\text { Optimal medical } \\
\text { treatment }\end{array}$ & $3.2 \%(n=4)$ & $3.8 \%(n=3)$ & 0.5 \\
\hline $\begin{array}{l}\text { Percutaneous } \\
\text { revascularization }\end{array}$ & $68.8 \%(n=86)$ & $68.0 \%(n=53)$ & 0.3 \\
\hline $\begin{array}{l}\text { Surgical } \\
\text { revascularization }\end{array}$ & $28.0 \%(n=35)$ & $28.2 \%(n=22)$ & 0.8 \\
\hline
\end{tabular}

\section{Discussion}

Modern research revealed a new horizon and function for 25(OH)D, beyond its proven role in the treatment of rickets and osteoporosis. 25(OH)D deficiency is believed to be associated with multiple sclerosis, respiratory diseases, many types of cancers, metabolic disorders, diabetes, and cardiovascular disease $(7-9,26-28)$.

Our results demonstrated that 25(OH)D deficiency was significantly associated with SMI in our population of well-selected type 2 diabetic patients, all with significant CAD. After adjusting for age, gender, body mass index, and season of 25(OH)D measurement, we demonstrated significantly lower serum levels in patients with SMI vs. patients with symptomatic $\mathrm{MI}$, no MI, and even in healthy volunteers.

Pain is a distressing sensation, as well as an emotional experience that is linked to actual or potential tissue damage, with the sole purpose of notifying the mechanism to react towards a stimulus to avoid further tissue damages. The sensation of pain is associated with the activation of the receptors in the

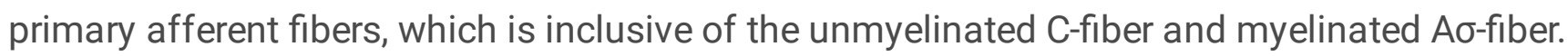

Because pain is mediated by small sensory fibers, our findings allow us to hypothesize that vitamin $D$ deficiency is possibly related to the presence of SMl; or promoting an abnormal transmission of pain, or thought-provoking a degenerative neuropathy of the small nociceptive nerve fibers. 
This view is supported by the experimental studies on the effects of 25(OH)D on the nervous system. $25(\mathrm{OH}) \mathrm{D}$ deficiency was associated with small nervous fibers neuropathy, involved in the transmission of pain $(22,24)$. Experimental data leading to the evidence that $25(\mathrm{OH}) \mathrm{D}$ have a pivotal role in the regulation of synthesis of neurotrophic factors, conductance velocity of motor neurons, neuronal plasticity processes, and the neuroprotective actions (29). Vitamin D receptors are widely expressed by the central and peripheral nervous systems (30). Particularly, in the peripheral nervous system, the vitamin $D$ receptors are found in predominantly nociceptive neurons of the dorsal root ganglia (31). The vitamin D receptors tend to rearrange itself in the neurons of diabetic rats (32), allowing us to suppose the role of low levels of vitamin $\mathrm{D}$ in the abnormal transmission of pain in diabetics.

Besides, v25(OH)D has an important role in promoting nerve growth factor (NGF) secretion. NGF is a target-derived protein that regulates the phenotype and sensibility of nociceptor fibers, and its deficiency may lead to the development of clinical diabetes small fibers neuropathy (33). A recent study has shown a positive correlation between $25(\mathrm{OH}) \mathrm{D}$ and serum NGF in diabetes patients $(33,34)$. A study in rodents reported deactivation of $25(\mathrm{OH}) \mathrm{D}$ in the presence of hyperglycemia (35). This may result in decreased vitamin D-mediated NGF secretion, which in turn could lead to a predominantly small nerve fibers neuropathy. In other words, it seems reasonable to assume a pathophysiological link between diabetes, low level of vitamin $D$, and compromising nociceptor fibers.

Several limitations must be recognized. First of all, this is an observational study, so it is not possible to establish causality, but only associations. An additional limitation regards the sample size, which was not calculated but derived from the number of patients who matched the strict inclusion criteria and the relatively small cohort size and the cross-sectional design. To minimize the impact of the sample size, we carefully characterized and matched patients in different cohorts. The only statistical significance between subgroups (patients with SMI vs. patients with angina) was higher body mass index and age, for patients in the SMI group. This was expected, like age, duration of diabetes, and features of metabolic syndrome (including obesity) are well-known risk factors for SMI (40). To address this, we included age, body mass index, duration of diabetes as covariates in the ANCOVA, and still found mean serum 25(OH)D levels were significantly lower in patients with SIM. Another limitation is that 25(OH)D plasma level is influenced by various factors: age, gender, ethnicity, skin color, season, and clothing. To overcome this limitation, we studied whether there was an imbalance regarding the season in which the dosage of $25(\mathrm{OH}) \mathrm{D}$ was affected. The studied groups, including that of healthy controls, resulted statistically comparable for this parameter. Furthermore, summer (from July to September) 25(OH)D dosage was inserted as a covariate in the statistical analysis, together with age and gender, and these parameters were not able to modify the final result. Moreover, all enrolled patients belonged to the same ethnic group and came from the same geographical area, so we postulated equal skin color and similar habits regarding sun exposure and clothing.

Several prognostic studies have shown that SMI is associated with an unfavorable outcome in clinical patients affected by acute myocardial infarction, unstable angina, and chronic stable CAD (34-37). In type 2 diabetic patients, SMI is an issue of public health a condition significantly related to mortality rate 
$(14,17,38,39)$. Survival analysis in our study confirmed an increased mortality risk in SMI type 2 diabetic patients compared to patients with angina, despite the same extent of CAD and the optimal revascularization obtained.

In conclusion, we conducted a carefully designed study that involved detailed clinical and invasive/noninvasive procedures, to accurately stratify the presence of CAD and $\mathrm{MI}$ in all enrolled patients. Our study included an appropriately matched disease control group (type 2 diabetic patients without $\mathrm{MI}$ ) and healthy volunteers. The findings suggest a role of 25(OH)D in MI. Our results also suggest that low levels of 25(OH)D may contribute to the development of diabetic-related neuropathy. Further long-term prospective studies are needed to examine causality, i.e. if low $25(\mathrm{OH}) \mathrm{D}$ levels make silent the $\mathrm{Ml}$, or if they are a risk factor/surrogate marker for the development of SMI. It may be reasonable to obtain plasma levels of $25(\mathrm{OH}) \mathrm{D}$ in all diabetic patients with significant $\mathrm{CAD}$ and to consider hypovitaminosis $\mathrm{D}$ as a factor potentially associated with SMI. It is also confirmed that SMI is a significant negative prognostic factor for mortality in type 2 diabetic patients. Whether hypovitaminosis $D$ will represent a therapeutic target for the treatment of neuropathy, or if it will be able to improve prognosis in diabetic patients with $\mathrm{Ml}$, it will have to be evaluated in subsequent randomized trials.

The current study provided a novel point of view on the role of low Vitamin D levels in SMI development in type 2 diabetes, never investigated before, to the best of our knowledge. Moreover, to remove possible confounders and considering vitamin D physiology, we excluded patients on vitamin D oral supplementation and those using sunbeds and recorded the season of vitamin D measurement. Then, we did not consider vitamin $D$ deficiency in our analysis but low vitamin $D$ levels. The reason is that low vitamin D levels that do not fulfill the strict definition of vitamin $D$ deficiency may have a pathogenetic role in SMI development.

Several limitations must be recognized. First of all, this is an observational study, so it is not possible to establish causality, but only associations. An additional limitation is the relatively small cohort size and the cross-sectional design. To minimize the impact of the sample size, we carefully characterized and matched patients in different cohorts. The only statistical significance between subgroups (patients with SMI vs patients with angina) was higher BMI and age, for patients in the SMI group. This was expected, like age, duration of diabetes, and features of metabolic syndrome (including obesity) are well-known risk factors for SMI (50). To address this, we included age, BMI, duration of diabetes as covariates in the ANCOVA, and still found mean serum 25(OH)D levels were significantly lower in patients with SIM.

Another limitation is that the vitamin D plasma level is influenced by various factors: age, gender, ethnicity, skin color, season, and clothing. To overcome this limitation, we studied whether there was an imbalance regarding the season in which the dosage of vitamin D was effected. The studied groups, including that of healthy controls, resulted statistically comparable for this parameter. Furthermore, summer (from July to September) determination of vitamin D was inserted as a covariate in the statistical analysis, together with age and gender, and these parameters were not able to modify the final result. Moreover, all enrolled patients belonged to the same ethnic group and came from the same 
geographical area, so we postulated equal skin color and similar habits regarding sun exposure and clothing.

\section{Conclusions}

In the current study, we established the importance of vitamin D levels on SMI development in the population of type 2 diabetic patients. Moreover, we demonstrated that SMI patients with low vitamin D levels had a worse prognosis than their symptomatic counterparts. These findings may open new horizons in risk-stratification, management, and prevention of cardiovascular complications in type 2 diabetes. Further prospective and larger studies are needed to better investigate and confirm the current study novel findings.

\section{List Of Abbreviations}

SMI (silent myocardial ischemia); MI (myocardial ischemia); 25-hydroxyvitamin D (25(OH)D); coronary heart disease (CAD); ergocalciferol (D2); cholecalciferol (D3); body mass index (BMI).

\section{Declarations}

\section{Ethics approval}

The current study protocol is in accordance with the Declaration of Helsinki and obtained the approval of the Ethics Committee of Modena University the 20/05/2020 with protocol number 0014071/20.

\section{Consent for publication}

Not applicable.

\section{Availability of data and materials}

The datasets used and analysed during the current study are available from the corresponding author on reasonable request.

\section{Competing Interest}

The authors have nothing to disclose.

\section{Funding}

This study receiven no funds.

\section{Authors' contributions}


R.R. and M. T. provided analysis, and interpretation of data and wrote the manuscript. C.R. provided data acquisition. G. B. and R. M. provided critical analysis of data and discussion and performed the revision of the manuscript. All the authors gave a substantial contribution to the work and approved the final version of the manuscript.

\section{Acknowledgements}

Not applicable.

\section{References}

1. Powers JM, Murphy JEJ. Sunlight radiation as a villain and hero: 60 years of illuminating research. Int J Radiat Biol. 2019;95:1043-9. DOI:10.1080/09553002.2019.1627440.

2. Webb AR, Kift R, Durkin MT, O'Brien SJ, Vail A, Berry JL, Rhodes LE. The role of sunlight exposure in determining the vitamin D status of the U.K. white adult population. Br J Dermatol. 2010;163:10505. DOI:10.1111/j.1365-2133.2010.09975.x.

3. Mithal A, Wahl DA, Bonjour JP, Burckhardt P, Dawson-Hughes B, Eisman JA, El-Hajj Fuleihan G, Josse RG, Lips P, Morales-Torres J, IOF Committee of Scientific Advisors (CSA) Nutrition Working Group. Global vitamin D status and determinants of hypovitaminosis D. Osteoporos Int. 2009;20:1807-20. DOI:10.1007/s00198-009-0954-6.

4. Vierucci F, Pistoia MD, Fanos M, Erba P, Saggese G. Prevalence of hypovitaminosis D and predictors of vitamin D status in Italian healthy adolescents. Ital J Pediatr. 2014;40:54. DOI:10.1186/18247288-40-54.

5. Colao A, Muscogiuri G, Rubino M, Vuolo L, Pivonello C, Sabatino P, Pizzo M, Campanile G, Fittipaldi R, Lombardi G, Di Somma C. Hypovitaminosis D in adolescents living in the land of sun is correlated with incorrect lifestyle: a survey study in Campania region. Endocrine. 2015;49:521-7.

DOI:10.1007/s12020-014-0483-8.

6. Beska B, Chan D, Gu S, Qiu W, Mossop H, Neely D, Kunadian V. The association between vitamin D status and clinical events in high-risk older patients with non-ST elevation acute coronary syndrome undergoing invasive management. PLoS One. 2019;14:e0217476.

DOI:10.1371/journal.pone.0217476.

7. Qi L, Ma W, Heianza Y, Zheng Y, Wang T, Sun D, Rimm EB, Hu FB, Giovannucci E, Albert CM, Rexrode $\mathrm{KM}$, Manson JE. Independent and synergistic associations of biomarkers of vitamin $D$ status with risk of coronary heart disease. Arterioscler Thromb Vasc Biol. 2017;37:2204-12.

DOI:10.1161/ATVBAHA.117.309548.

8. Liu L, Chen M, Hankins SR, Nùñez AE, Watson RA, Weinstock PJ, Newschaffer CJ, Eisen HJ, Drexel Cardiovascular Health Collaborative Education, Research, and Evaluation Group. Serum 25hydroxyvitamin D concentration and mortality from heart failure and cardiovascular disease, and premature mortality from all-cause in United States adults. Am J Cardiol. 2012;110:834-9. DOI:10.1016/j.amjcard.2012.05.013. 
9. Zhu K, Knuiman M, Divitini M, Hung J, Lim EM, Cooke BR, Walsh JP. Serum 25-hydroxyvitamin D as a predictor of mortality and cardiovascular events: A 20-year study of a community-based cohort. Clin Endocrinol (Oxf). 2018;88:154-63. DOI:10.1111/cen.13485.

10. Li J, Lai H, Yang L, Zhu H, Chen S, Lai S. Age and gender differences in the association between serum 25-hydroxyvitamin D and stroke in the general US population: the National Health and Nutrition Examination Survey, 2001-2006. J Stroke Cerebrovasc Dis. 2017;26:2510-8. DOI:10.1016/j.jstrokecerebrovasdis.2017.05.045.

11. Oz F, Cizgici AY, Oflaz H, Elitok A, Karaayvaz EB, Mercanoglu F, Bugra Z, Omer B, Adalet K, Oncul A. Impact of vitamin $D$ insufficiency on the epicardial coronary flow velocity and endothelial function. Coron Artery Dis. 2013;24:392-7. DOI:10.1097/MCA.0b013e328362b2c8.

12. Karohl C, Vaccarino V, Veledar E, Goldberg J, Tangpricha V, Bellasi A, Raggi P. Vitamin D status and coronary flow reserve measured by positron emission tomography: a co-twin control study. J Clin Endocrinol Metab. 2013;98:389-97. DOl:10.1210/jc.2012-3097.

13. Safaie N, Rezaee H, Seif Dvati B, Entezari-Maleki T. Vitamin D deficiency predicts the ST elevation type of myocardial infarction in patients with acute coronary syndrome. Iran J Pharm Res. 2018;17(suppl):73-8. PMCID: PMC5958326.

14. BARI Investigators. Seven-year outcome in the Bypass Angioplasty Revascularization Investigation (BARI) by treatment and diabetic status. J Am Coll Cardiol. 2000;35:1122-9. DOI:10.1016/s07351097(00)00533-7.

15. Jouven X, Lemaître RN, Rea TD, Sotoodehnia N, Empana JP, Siscovick DS. Diabetes, glucose level, and risk of sudden cardiac death. Eur Heart J. 2005;26:2142-7. DOI:10.1093/eurheartj/ehi376.

16. Eranti A, Kerola T, Aro AL, Tikkanen JT, Rissanen HA, Anttonen O, Junttila MJ, Knekt P, Huikuri HV. Diabetes, glucose tolerance, and the risk of sudden cardiac death. BMC Cardiovasc Disord. 2016;16:51. DOI:10.1186/s12872-016-0231-5.

17. Laukkanen JA, Mäkikallio TH, Ronkainen K, Karppi J, Kurl S. Impaired fasting plasma glucose and type 2 diabetes are related to the risk of out-of-hospital sudden cardiac death and all-cause mortality. Diabetes Care. 2013;36:1166-71. DOI:10.2337/dc12-0110.

18. Cohn PF. Silent myocardial ischemia in patients with a defective angina warning system. Am J cardiol. 1980;45:697-702. DOI:10.1016/s0002-9149(80)80024-5.

19. Marchant B, Umachandran V, Stevenson R, Kopelman PG, Timmis AD. Silent myocardial ischemia: role of subclinical neuropathy in patients with and without diabetes. J Am Coll Cardiol. 1993;22:1433-7. DOI:10.1016/0735-1097(93)90554-e.

20. Bosone D, Fogari R, Ramusino MC, Ghiotto N, Guaschino E, Zoppi A, D'Angelo A, Costa A. Ambulatory 24-h ECG monitoring and cardiovascular autonomic assessment for the screening of silent myocardial ischemia in elderly type 2 diabetic hypertensive patients. Heart Vessels. 2017;32:507-13. DOI:10.1007/s00380-016-0898-7.

21. Baltzis D, Roustit M, Grammatikopoulou MG, Katsaboukas D, Athanasiou V, lakovou I, Veves A, Manes C, Trakatelli MC. Diabetic Peripheral Neuropathy as a Predictor of Asymptomatic Myocardial 
Ischemia in Type 2 Diabetes Mellitus: A Cross-Sectional Study. Adv Ther. 2016;33:1840-7. DOI:10.1007/s12325-016-0399-1.

22. Filipovic N, Ferhatovic L, Marelja I, Puljak L, Grkovic I. Increased vitamin D receptor expression in dorsal root ganglia neurons of diabetic rats. Neurosci Lett. 2013;549:140-5. DOI:10.1016/j.neulet.2013.05.023.

23. Ahmad MI, Chevli PA, Li Y, Soliman EZ. Vitamin D deficiency and electrocardiographic subclinical myocardial injury: Results from National Health and Nutrition Examination Survey-III. Clin Cardiol. 2018;41:1468-73. DOI:10.1002/clc.23078.

24. Lv WS, Zhao WJ, Gong SL, Fang DD, Wang B, Fu ZJ, Yan SL, Wang YG. Serum 25-hydroxyvitamin D levels and peripheral neuropathy in patients with type 2 diabetes: a systematic review and metaanalysis. J Endocrinol Invest. 2015;38:513-8. DOI:10.1007/s40618-014-0210-6.

25. Zhou YK, Liang Z, Guo Y, Zhang HT, Wang KH. High glucose upregulates CYC24A1 expression which attenuates the ability of 1,25 (OH) 2D3 to increase NGF secretion in a rat Schwann cell line RSC96. Mol Cell Endocrinol. 2015;404:75-81. DOI:10.1016/j.mce.2015.01.005.

26. Abdollahzadeh R, Fard MS, Rahmani F, Moloudi K, Kalani BS, Azarnezhad A. Predisposing role of vitamin $\mathrm{D}$ receptor polymorphisms in the development of multiple sclerosis. J Neurol Sci. 2016;367:148-51. DOI:10.1016/j.jns.2016.05.053.

27. Sismanlar T, Aslan AT, Gulbahar O, Ozkan S. The effect of vitamin D on lower respiratory tract infection in children. Turk Pediatri Arsivi. 2016;51:94. DOI:10.5152/TurkPediatriArs.2016.3383.

28. Wang K, Dong M, Sheng W, Liu Q, Yu D, Dong Q, Li Q, Wang Y. Expression of vitamin D receptor as a potential prognostic factor and therapeutic target in pancreatic cancer. Histopathology. 2015;67:386-97. DOI:10.1111/his.12663.

29. Fernandes de Abreu DA, Eyles D, Feron F. Vitamin D. a neuro-immunomodulator: implications for neurodegenerative and autoimmune diseases. Psychoneuroendocrinology. 2009;34(Suppl. 1):26577. DOI:10.1016/j.psyneuen.2009.05.023.

30. Prufer K, Veenstra TD, Jirikowski GF, Kumar R. Distribution of 1,25-dihydroxyvitamin D3 receptor immunoreactivity in the rat brain and spinal cord. J Chem Neuroanat. 1999;16:135-45. DOI:10.1016/s0891-0618(99)00002-2.

31. Tague SE, Smith PG. Vitamin D receptor and enzyme expression in dorsal root ganglia of adult female rats: modulation by ovarian hormones. J Chem Neuroanat. 2011;41:1-12.

DOI:10.1016/j.jchemneu.2010.10.001.

32. Anand P, Terenghi G, Warner G, Kopelman P, William-Chestnut RE, Sinicropi DV. The role of endogenous nerve growth factor in human diabetic neuropathy. Nat Med. 1996;2:703-7. DOI:10.1038/nm0696-703. 32.

33. Ozuguz U, Orac S, Ulu MS, Demirbas H, Acay A, Coker B, Beyazıt B, Yaman M, Koken T. Does vitamin $D$ have any role in the improvement of diabetic peripheral neuropathy in type 1 diabetic patients? J Endocrinol Invest. 2016;39:1411-7. DOI:10.1007/s40618-016-0509-6. 
34. Assey ME, Walters GL, Hendrix GH, Carabello BA, Usher BW, Spann JF. Incidence of acute myocardial infarction in patients with exercise-induced silent myocardial ischemia. Am J Cardiol. 1987;59:497500. DOI:10.1016/0002-9149(87)91155-6.

35. Gottlieb SO, Gottlieb SH, Achuff SC, Baumgardner R, Mellis ED, Weisfeldt ML, Gerstemblith G. Silent ischemia on holter monitoring predicts mortality in high-risk postinfarction patients. JAMA. 1988;259:1030-5. PMID: 3339800.

36. Egstrup K. Asyntomatic myocardial ischemia as a predictor of cardiac events after coronary artery bypass grafting for stable angina pectoris. Am J Cardiol. 1988;61:248-52. DOI:10.1016/00029149(88)90925-3.

37. Choi KH, Lee JM, Park I, Kim J, Rhee T, Hwang D, Park J, Park TK, Yang JH, Song YB, Hahn J, Jeong DS, Cho YH, Kim WS, Sung K, Jang MJ, Sung JD, Choi J, Choi S, Koo B, Lee YT, Kim EK, Chang S, Park S, Choi J, Lee S, Park SW, Cho YS, Choi JY, Gwon H, Oh JK. Comparison of long-term clinical outcomes between revascularization versus medical treatment in patients with silent myocardial ischemia. Int J Cardiol. 2019;277:47-53. D0I:10.1016/j.ijcard.2018.08.006.

38. Chiariello M, Indolfi C. Silent myocardial ischemia in patients with diabetes mellitus. Circulation. 1996;93:2089-91. DOI:10.1161/01.cir.93.12.2089.

39. Ditchburn CJ, Hall JA, de Belder M, Davies A, Kelly W, Bilous R. Silent myocardial ischaemia in patients with proved coronary artery disease: a comparison of diabetic and non-diabetic patients. Postgrad Med J. 2001;77:395-8. DOl:10.1136/pmj.77.908.395.

40. Fredenrich A, Castillo-Ros S, Hieronimus S, Baudouy M, Harter M, Canivet B. Screening for silent myocardial ischemia in diabetic patients. Diabetes Care. 2000;23:563.

DOI:10.2337/diacare.23.4.563.

\section{Figures}




\section{\% survival}

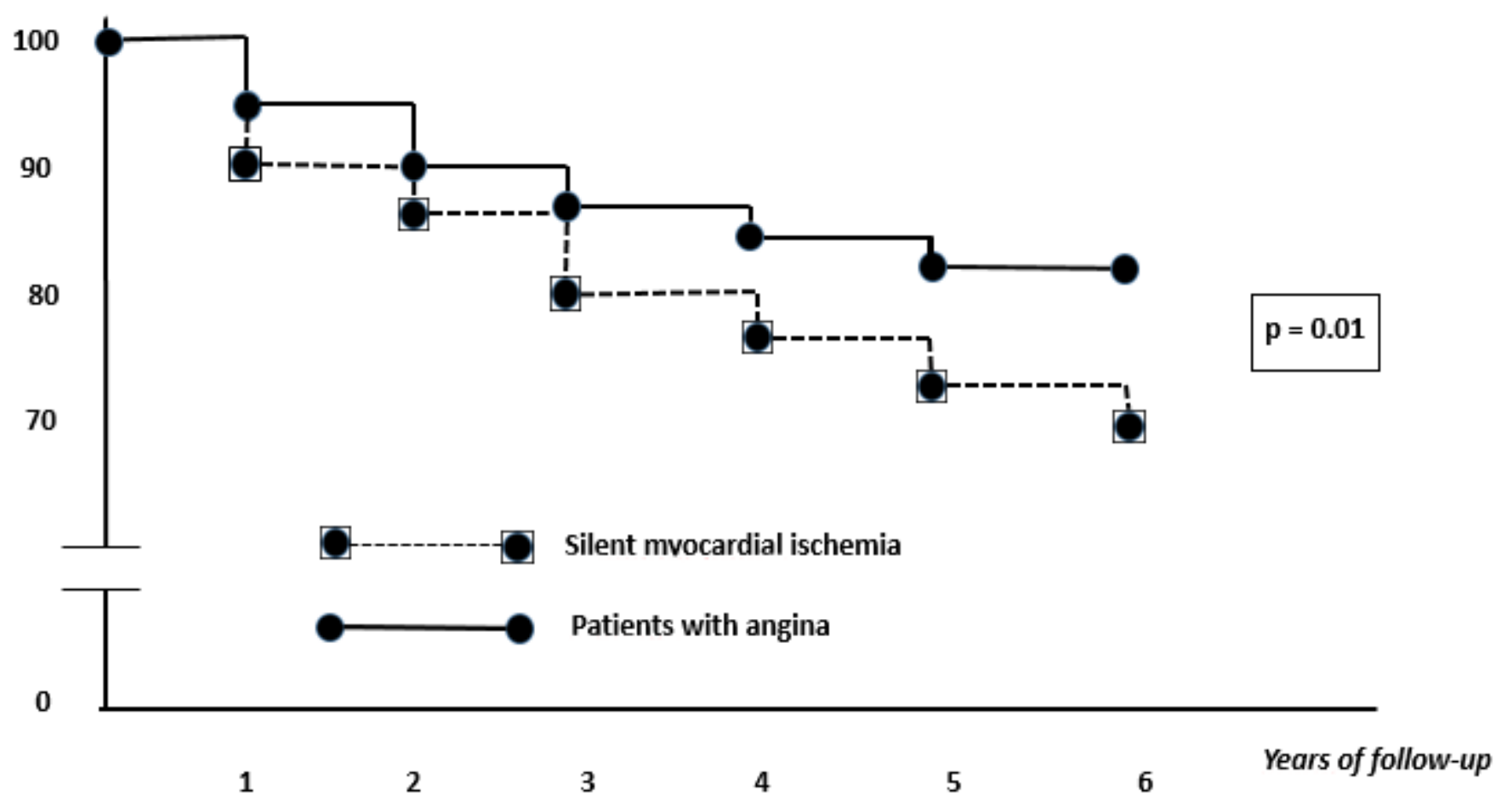

Figure 1

Six-year survival of diabetic patients with silent myocardial ischemia vs. symptomatic ischemia. 